\title{
HIGH-RESOLUTION DEBRIS FLOW VOLUME MAPPING WITH UNMANNED AERIAL SYSTEMS (UAS) AND PHOTOGRAMMETRIC TECHNIQUES
}

\author{
M.S. Adams ${ }^{a *}$, R. Fromm ${ }^{a}$, V. Lechner ${ }^{a}$ \\ a Dept. of Natural Hazards, Austrian Forest Research Centre (BFW), Rennweg 1, 6020 Innsbruck, Austria - (marc.adams, \\ reinhard.fromm, veronika.lechner)@bfw.gv.at
}

KEY WORDS: Unmanned Aerial Vehicle, Structure-from-motion, Natural Hazards, Volumetric Sediment Budget, Digital Terrain Models, Event Documentation

\begin{abstract}
:
Debris flows cause an average $€ 30$ million damages and 1-2 fatalities every year in Austria. Detailed documentation of their extent and magnitude is essential for understanding, preventing and mitigating these natural hazard events. The recent development of unmanned aerial systems (UAS) has provided a new possibility for on-demand high-resolution monitoring and mapping. Here, we present a study, where the spatial extent and volume of a large debris flow event were mapped with different UAS, fitted with commercial off-the-shelf sensors. Orthophotos and digital terrain models (DTM) were calculated using structure-from-motion photogrammetry software. Terrain height differences caused by the debris flow in the catchment and valley floor were derived by subtracting the pre-event airborne laser scanning (ALS) DTM from a post-event UAS-DTM. The analysis of the volumetric sediment budget showed, that approximately $265,000 \mathrm{~m}^{3}$ material was mobilised in the catchment, of which $45,000 \mathrm{~m}^{3}$ settled there; of the material, which reached the valley floor, $120,000 \mathrm{~m}^{3}$ was deposited, while another $10,000 \mathrm{~m}^{3}$ was eroded from there. The UASresults were validated against ALS data and imagery from a traditional manned-aircraft photogrammetry campaign. In conclusion, the UAS-data can reach an accuracy and precision comparable to manned aircraft data, but with the added benefits of higher flexibility, easier repeatability, less operational constraints and higher spatial resolution.
\end{abstract}

\section{INTRODUCTION}

Debris flows are described as 'rapid, gravity-induced mass movements consisting of a mixture of water, sediment, wood and anthropogenic debris that propagate along channels incised on mountain slopes and onto debris fans' (Gregoretti et al., 2016). These natural hazard events have a substantial impact on the quality of life in mountainous regions: In Austria, the examination of 5,000 debris flows, recorded between 1972 and 2004 , resulted in a total estimated damage of $€ 965$ million and 49 fatalities (Oberndorfer et al., 2007). Promptly mapping the consequences of these events by determining the spatial extent and volume of eroded and deposited material, is highly relevant to scientists and practitioners, e.g. for numerical simulation modelling (Rickenmann et al., 2006; Han et al., 2015), process understanding (Theule et al., 2015; Pellegrino et al., 2015), and natural hazard management (Ballesteros Cánovas et al., 2016; Aronica et al., 2012). Conventional mapping techniques mostly require personnel to directly access the process area (catchment and valley floor), which is a hazardous or even impossible task. Additional data acquisition from terrestrial (e.g. terrestrial laser scanning), airborne (e.g. traditional photogrammetry from manned aircraft) or spaceborne sources (e.g. high-resolution satellite imagery) is typically only commissioned in case of large-scale events (Linder et al., 2015).

In recent years, the development of unmanned aerial systems (UAS) (Colomina \& Molina, 2014) has provided a wide range of new possibilities for high resolution monitoring and mapping (Lucieer et al., 2014). UAS are able to bridge the gap between full-scale, manned aerial, and terrestrial observations (Briese et al., 2013; Rosnell \& Honkavaara, 2012). They are credited as being able to supply on-demand imagery at an unprecedented level of detail (ground resolution of few centimetres or millimetres) (Lucieer et al., 2014), in a cost-efficient and flexible manner, albeit over small areas $\left(<1 \mathrm{~km}^{2}\right)$ (Bühler et al., 2016; Ryan et al., 2015). Additionally, the development of novel computer vision techniques (structure-from-motion) and their implementation into commercially available software packages (e.g. Agisoft Photoscan Pro) have reduced the requirements for the recorded data (Vander Jagt et al., 2015; Turner et al., 2012). This development makes high-performance algorithms for 3D-processing more readily available to the UAS-community (Mancini et al., 2013; Hugenholtz et al., 2013).

Recent studies dealing with the application of UAS in natural hazard monitoring mainly focus on landslides (e.g. Lindner et al., 2015), rockfall (e.g. Danzi et al., 2014), glaciers (e.g. Bhardwaj et al., 2016) or rock glaciers (e.g. Dall'Asta et al., 2015). However, to our knowledge, so far very few publications exist that deal with UAS-based debris flow event mapping (Sotier et al., 2013; Wen et al., 2011). The use of other remote sensing data for this task, reported in the current literature, include high-resolution satellite imagery (Youssef et al., 2014; Elkadiri et al., 2014), manned aircraft photographs (Dietrich \& Krautblatter, 2016), airborne laser scanning (ALS) (Bull et al., 2010; Scheidl et al., 2008) or a combination of the above (Willi et al., 2015).

The objective of this paper is to present the use of UAS-data to map the extent and calculate the volumetric sediment budget of a debris flow event, i.e. the total volume of eroded and deposited material in the catchment and valley floor.

\footnotetext{
* Corresponding author
} 


\section{STUDY SITE}

The study site is situated in the Sellrain Valley of the Stubaier Alps, central Tyrol, Austria $\left(47^{\circ} 12^{\prime} \mathrm{N}, 11^{\circ} 12^{\prime} \mathrm{E}\right.$ ) (Figure 1, top left). It is a tributary to the Inn Valley and has a population of approximately 2,200. The valley's V-shape narrows down the space available for settlements and infrastructure, which are often endangered by natural hazards (Bitschnau \& Obermair, 2012). The debris flow originated in the catchment of the Seigesbach torrent, a tributary to the Melach - the main river draining the valley. Prior to 2015, several smaller events and one with comparable magnitude (in 1928) had been recorded (Fliri, 1998). Therefore, no mitigation measures had been constructed in the Seigesbach torrent. The entire catchment comprises an area of about $4 \mathrm{~km}^{2}$ and reaches its highest point at the Fotscher Windegg (2,577 $\mathrm{m}$ a.s.1.). The land cover in the catchment is dominated by spruces (Picea abies) and alpine meadows. The majority of the debris was deposited in the valley floor in the western part of the village Sellrain. The valley floor lies at approximately $950 \mathrm{~m}$ a.s.l. and is mainly characterised by meadows, with small clusters of buildings and patches of wooded areas. The main road connection through the valley (Sellrainstraße, L13) runs along the upper section of Figure 1, top right. The areas of interest (AOI), where the UAS-data was collected and the centre of Sellrain are also indicated in this figure.
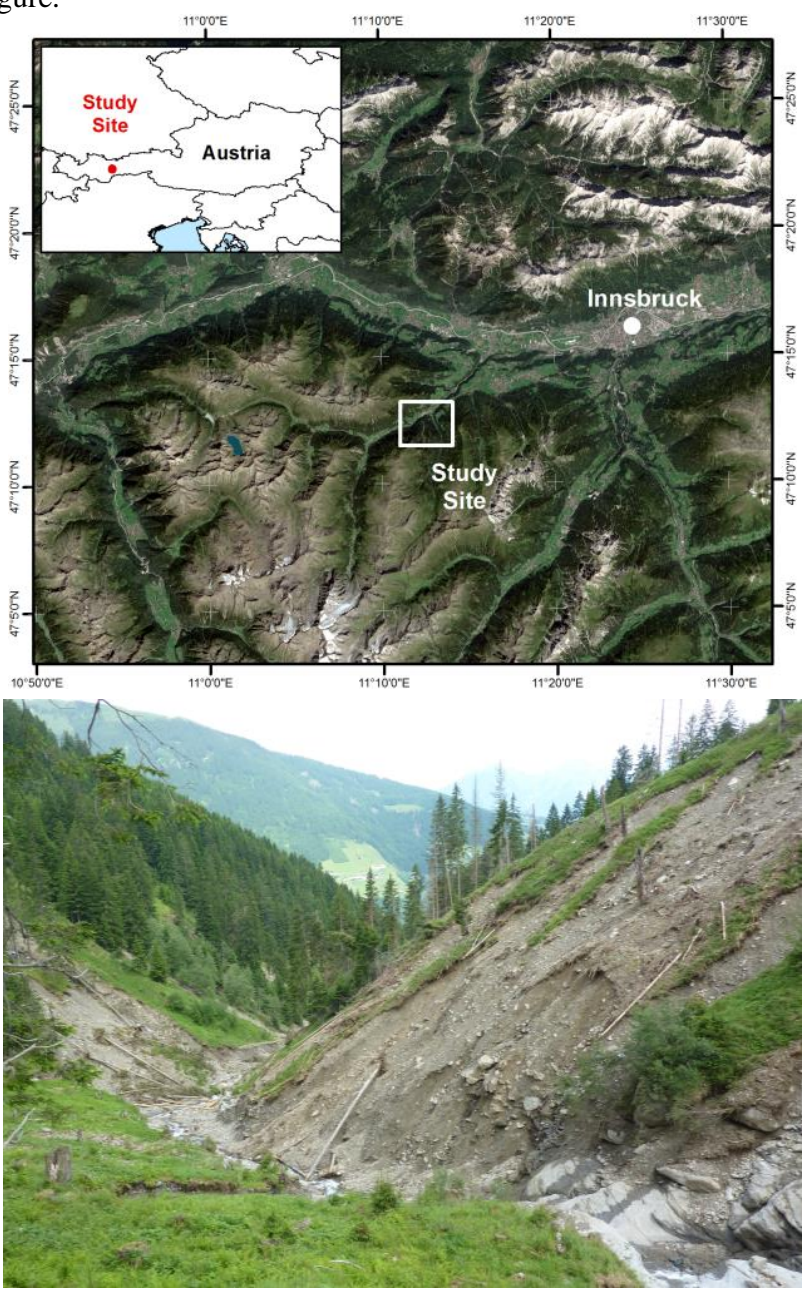

\subsection{Debris Flow Event Description}

In May 2015, the precipitation rate in the study area exceeded the long-term average by approximately $80 \%$ (Drechsler, 2015). During the last days of May, almost the entire catchment was covered by snow. By 6 June 2015, one day prior to the event, the entire snow cover had melted. This snowmelt, combined with elevated precipitation leading up to the event, resulted in heavily waterlogged ground in the catchment. During the evening of 6 June, extraordinarily high amounts of precipitation reached the catchment. On 7 June, an intense, almost stationary thunderstorm with hail occurred, triggering the debris flow. The precipitation reached up to $110 \mathrm{~mm}$ in six hours (Drechsler, 2015). The event culminated in a large debris flow, covering parts of the valley floor with a big alluvial cone in a comparatively short time. Two buildings were totally destroyed and a further 15 damaged; three road bridges were damaged or destroyed, the main road connection was impacted over $300 \mathrm{~m}$ length and interrupted for several months; four hectares of green and willow land was affected; no damage to persons occurred, but livestock was lost (Jenner, 2015). The authorities later estimated a total damage of approximately $€ 30$ million (ORF, 2015).
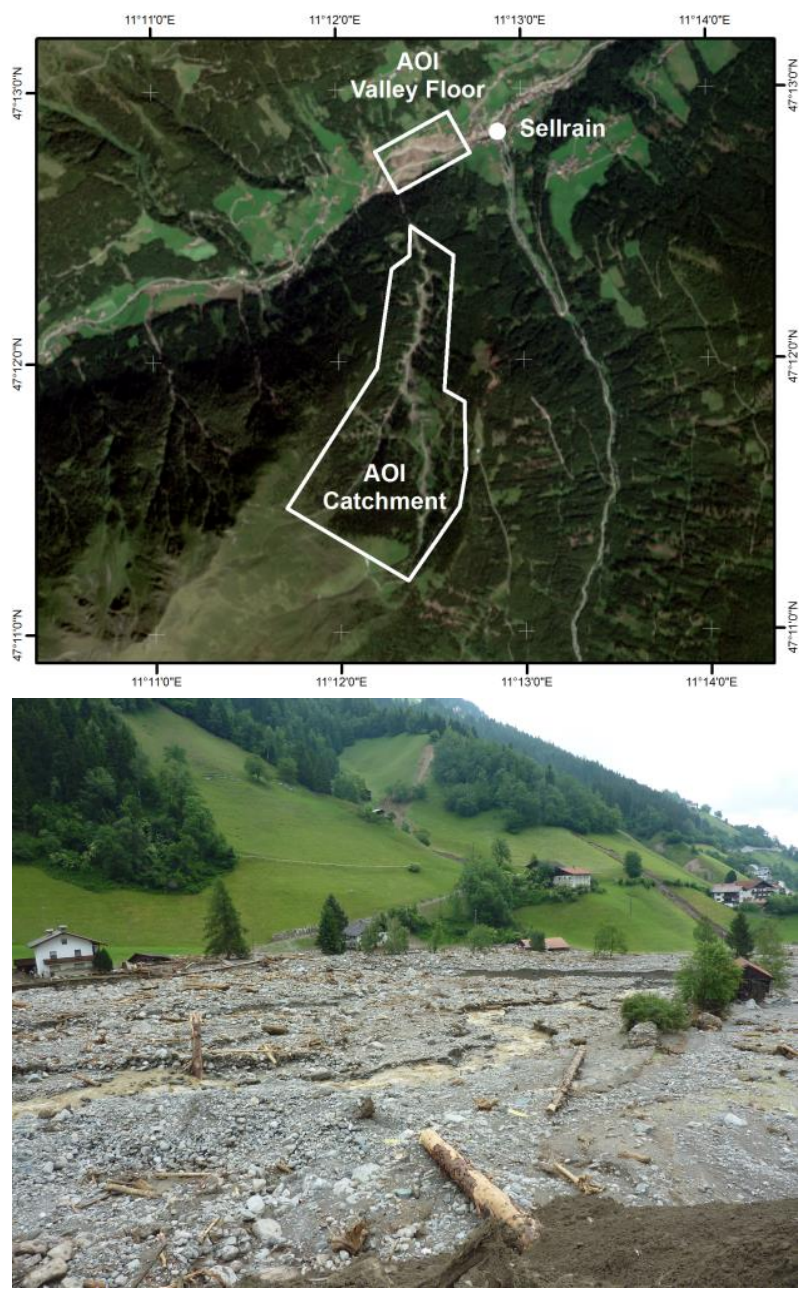

Figure 1. Location of study site in Austria (top left); overview of AOI of the UAS-flights (top right); terrestrial photographs of the catchment on 18 June 2015 (bottom left) and the valley floor on 9 June 2015 (bottom right) (sources: administrative boundaries GADM, 2016; imagery top row - ESA Sentinel 2A, 2016; photographs bottom row - Pittracher WLV, 2015) 


\subsection{Data Acquisition}

The valley floor $\left(0.3 \mathrm{~km}^{2}\right)$ was mapped on 9 June 2015 with an AustroDrones X18 UAS, which is an electric-powered octocopter in X8-configuration with four arms, each supporting two propellers (Figure 2, left). The UAS mapped the same AOI on two consecutive flights. For image collection, a mirror-less, full-frame commercial off-the-shelf camera was used: Sony Alpha 7R with a $35 \mathrm{~mm}$ prime lens. It was mounted below the UAS on a three-axis gimbal, which was isolated from the motor vibration of the UAS, to avoid image blur. The gimbal and the sensor were remotely controlled from the ground control station and set to keep the camera in nadir.

On 26 June 2015, those parts of the Seigesbach catchment relevant to the debris flow event, were charted $\left(2.5 \mathrm{~km}^{2}\right)$. We used a custom-built fixed-wing UAS (Multiplex Mentor Elapor), because it is capable of long range $(<1,500 \mathrm{~m})$ and endurance (flight time 30-40 minutes) (Figure 2, right). The UAS was fitted with a Sony NEX5 (16 mm focal length, 14 MP sensor resolution), integrated into the fuselage.
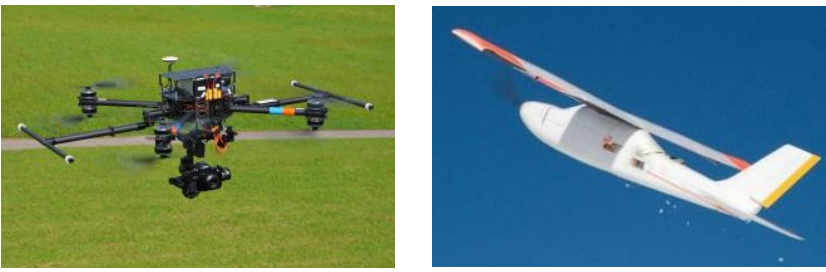

Figure 2. AustroDrones X18 (left - source: Austro Drones) and BFW Mentor (right)

On all flights, the cameras' shutter speed, aperture and ISO were chosen to maximise image quality and avoid motion blur (1/400-1/640, f/4-f/18, ISO 400-1000, respectively). Table 1 summarises the details of the six UAS-flights at the study site. The UAS both featured integrated global navigation satellite system / inertial measurement unit (GNSS/IMU) components, connected to an autopilot, and were therefore capable of automatically following a pre-defined flight path. The technical specifications of the UAS and the deployed sensors are provided in the Appendix - Table 3 \& Table 4, respectively.

\begin{tabular}{|l|c|c|}
\hline & Valley Floor & Catchment \\
\hline UAV-type & Multicopter & Fixed-wing \\
No. UAV-flights & 2 & 4 \\
No. images & 640 & 4000 \\
Size area $\left[\mathrm{km}^{2}\right]$ & 0.3 & 2.5 \\
Flight time $[\mathrm{minutes}]$ & 25 & 80 \\
Height a.g.l. [m] & 150 & 150 \\
Overlap (forward / side) [\%] & $85 / 75$ & $80 / 80$ \\
GCPs & 10 & 20 \\
\hline
\end{tabular}

Table 1. Details of UAS-flights

As the UAS were not equipped with high-quality (i.e. surveygrade) GNSS receivers to determine their location in space, indirect georeferencing with ground control had to be used (e.g. Nolan et al., 2015; Harwin et al., 2015). Prior to the UASflights, 30 ground control points (GCP), consisting of $0.4 \times 0.4 \mathrm{~m}$ black and white checkered wooden boards were placed at predefined locations in the catchment and valley floor AOIs, which were not affected by the debris flow. The position of the GCPs was recorded using a terrestrial GNSS (Trimble GeoExplorer XT 2008, expected accuracy x/y-direction 0.1, zdirection $0.2 \mathrm{~m}$ ) with an external antenna (model: Hurricane), capable of receiving single-frequency GPS (global positioning system) data. Real-time correction was used in the field and differential correction from the scripps orbit and permanent array centre in Bolzano ( $80 \mathrm{~km}$ from the study site) applied in the office via the Trimble software Pathfinder Office (Trimble, 2015). The final $x-, y-\&$ z-coordinates of each GCP were averaged from the $>200$ points recorded at each GCP location.

Data on the height of the pre-event terrain was available from two ALS campaigns commissioned by the Province of Tyrol: the catchment was mapped in 2009 with a ground sampling distance (GSD) of $1 \mathrm{~m}$, the valley floor in 2014 with a $0.5 \mathrm{~m}$ GSD.

\section{VOLUME MAPPING}

\subsection{Photogrammetric reconstruction}

The UAS-images were processed with Agisoft's Photoscan Pro (version 1.1.6) (Agisoft LLC, 2016), a commercially available photogrammetric software suite, that is widely spread in the UAS-community (Tonkin et al., 2014). It is based on a structure-from-motion algorithm and provides a complete, photogrammetric workflow, with particular emphasis on multiview stereopsis (Harwin et al., 2015): i) tie point matching; ii) bundle adjustment (here constrained by assigning high weights to the GCP coordinates - known as indirect georeferencing or conventional aerotriangulation (Vander Jagt et al., 2015)); iii) linear 7-parameter conversion; removal of non-linear deformations; iv) dense point cloud (DPC) generation with multiview stereo reconstruction; v) export of georeferenced orthophotos and digital elevation models (DEM). We referenced all data to the respective standard national coordinate systems (EPSG-Code 31254, Gebrauchshöhen Adria).

The height values of the DEMs derived from the photogrammetrically calculated DPC (Figure 3, left) generally refer to the height above sea level of the terrain, buildings or vegetation, captured in the scene. It is therefore more accurate refer to them as digital surface models (DSM) (Weibel \& Heller, 1991). When estimating the deposition and erosion volumes of the debris flow, we calculated the change in terrain height. We therefore removed all objects above or on the terrain, from the DSM, resulting in a digital terrain model (DTM) (Weibel \& Heller, 1991). The DTMs were generated by classifying the DPC in Photoscan into ground and non-ground points (Figure 3, right). For those areas, where no ground points are available, Photoscan performs a linear interpolation of the surface.

The resulting orthophotos (Figure 4, left) and DSM (Figure 4, right) of the valley floor and catchment, featured a GSD of $0.02 / 0.05 \mathrm{~m}$ and $0.08 / 0.2 \mathrm{~m}$, respectively, with lower average GSD in the catchment. The mean effective overlap of the UASdata was 8-16 images. The DEMs were calculated from photogrammetric DPCs, which have an average point density of $30-160$ points $/ \mathrm{m}^{2}$. 

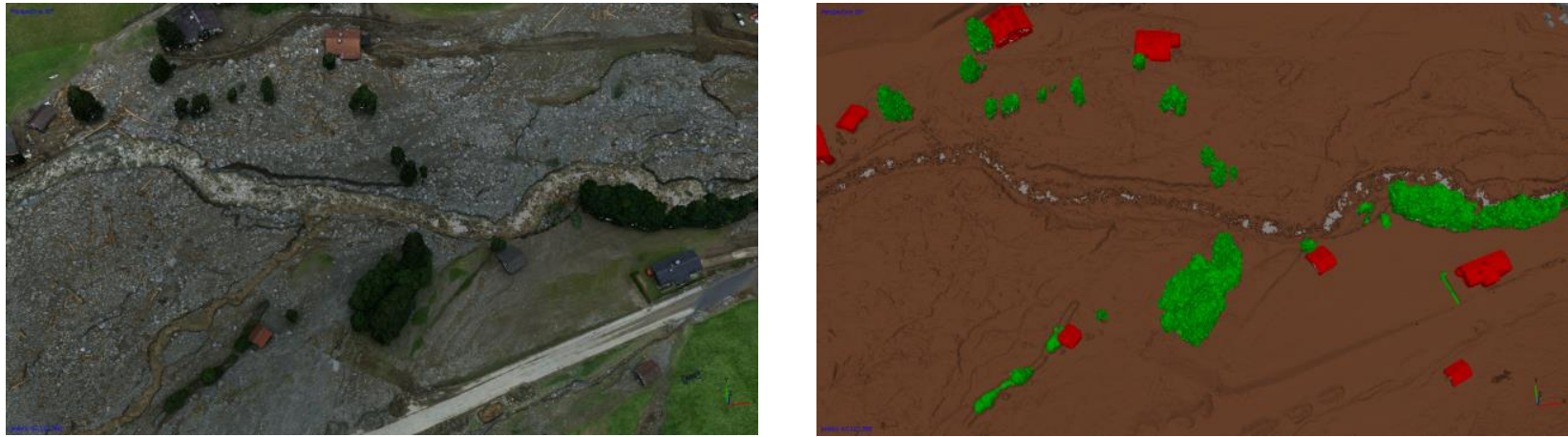

Figure 3. Photogrammetric processing of the valley floor - RGB-coloured DPC (left); classification of DPC into ground (brown), vegetation (green) and buildings (red) (gaps in DPC - grey) (right)
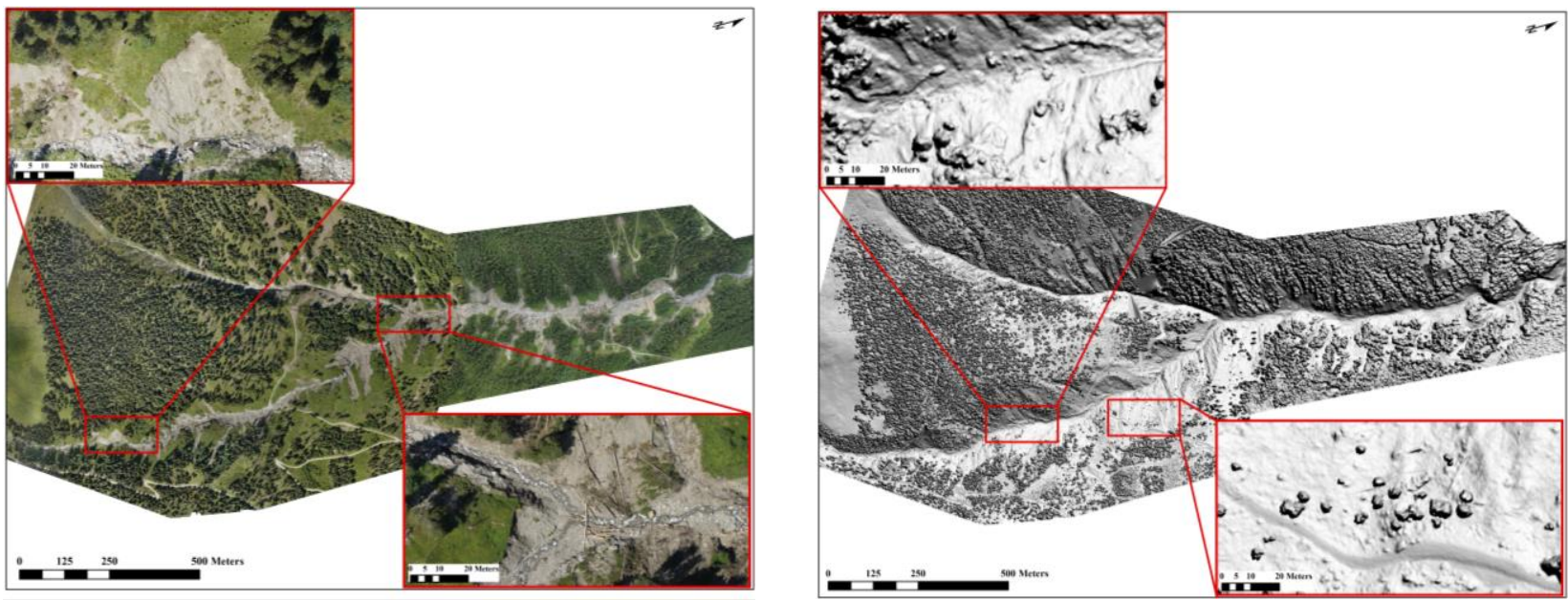

Figure 4. Results from the photogrammetric processing - orthophoto (left) and digital surface model (right) of the catchment

\subsection{Volume Calculation}

The terrain height change caused by the debris flow was calculated by subtracting the pre-event ALS-DTM from the post-event UAS-DTM. These difference DTMs (dDTM) thus provide information on the amount of deposition (positive values) and erosion (negative values) of debris for each pixel (Nolan et al., 2015). We estimated the total volume of debris deposition and erosion, by summing up the ADTM pixel values within the AOIs. To avoid possible artefacts resulting from the DTM-interpolation, we masked out buildings and vegetation areas. To counter systematic error in the dDTM resulting from different height reference systems, we extracted the z-values of all GCPs from the ALS DTM.

Figure 5 (top) shows the results of the volumetric sediment budget calculation for the valley floor, coloured by erosion (blue) and deposition (brown). The majority of debris collected in the riverbed of the Melach (s-shaped feature in upper part of the figure). Here deposition depths reached up to $10 \mathrm{~m}$, as also evidenced by the cross-section (Figure 5, centre left). While overall the deposition dominates, isolated patches of erosion were also detected. The highest erosion values $(>4 \mathrm{~m})$ are reached on the left bank of the Seigesbach torrent, which enters the figure from the bottom left. The results from the valley floor (Figure 5, bottom) highlight the extent of erosion of material from the catchment. Large sections of this part of the catchment lie in forested areas, therefore the mass balance calculation was limited to the gully (red outline in figure) to avoid errors introduced by vegetation height differences between ALS and UAS data. The cross-section (Figure 5, centre right) reveals erosion values of 3-4 $\mathrm{m}$ in the lower part of the gully, while values in the central and upper sections reach $8 \mathrm{~m}$. Isolated patches of deposited material were also detected.

The total debris flow mass balance calculation showed that $265,000 \mathrm{~m}^{3}\left( \pm 42,000 \mathrm{~m}^{3}\right)$ material was mobilised in the catchment, of which $45,000 \mathrm{~m}^{3}\left( \pm 13,000 \mathrm{~m}^{3}\right)$ settled there; of the material, which reached the valley floor, $120,000 \mathrm{~m}^{3}$ $\left( \pm 5,000 \mathrm{~m}^{3}\right)$ was deposited there, while another $10,000 \mathrm{~m}^{3}$ $\left( \pm 2,000 \mathrm{~m}^{3}\right)$ was eroded.

\subsection{Validation of Results}

Accuracy and precision of the UAS-results was calculated by comparison with manned aircraft imagery, ALS data, extensive fieldwork and a second UAS-flight in the valley floor. The accuracy of the UAS-data lies within $0.05-0.15 \mathrm{~m}$ (root mean square error - RMSE) and 0.3-0.5 $\mathrm{m}$ in xyz-directions, for the valley floor and catchment, respectively. The uncertainty range of the mass balance calculation above corresponds to this RMSE. The precision in the valley floor was derived from the second UAS-flight - it lies at $0.05 \mathrm{~m}$. A more advanced analysis of accuracy and precision is currently in preparation. 

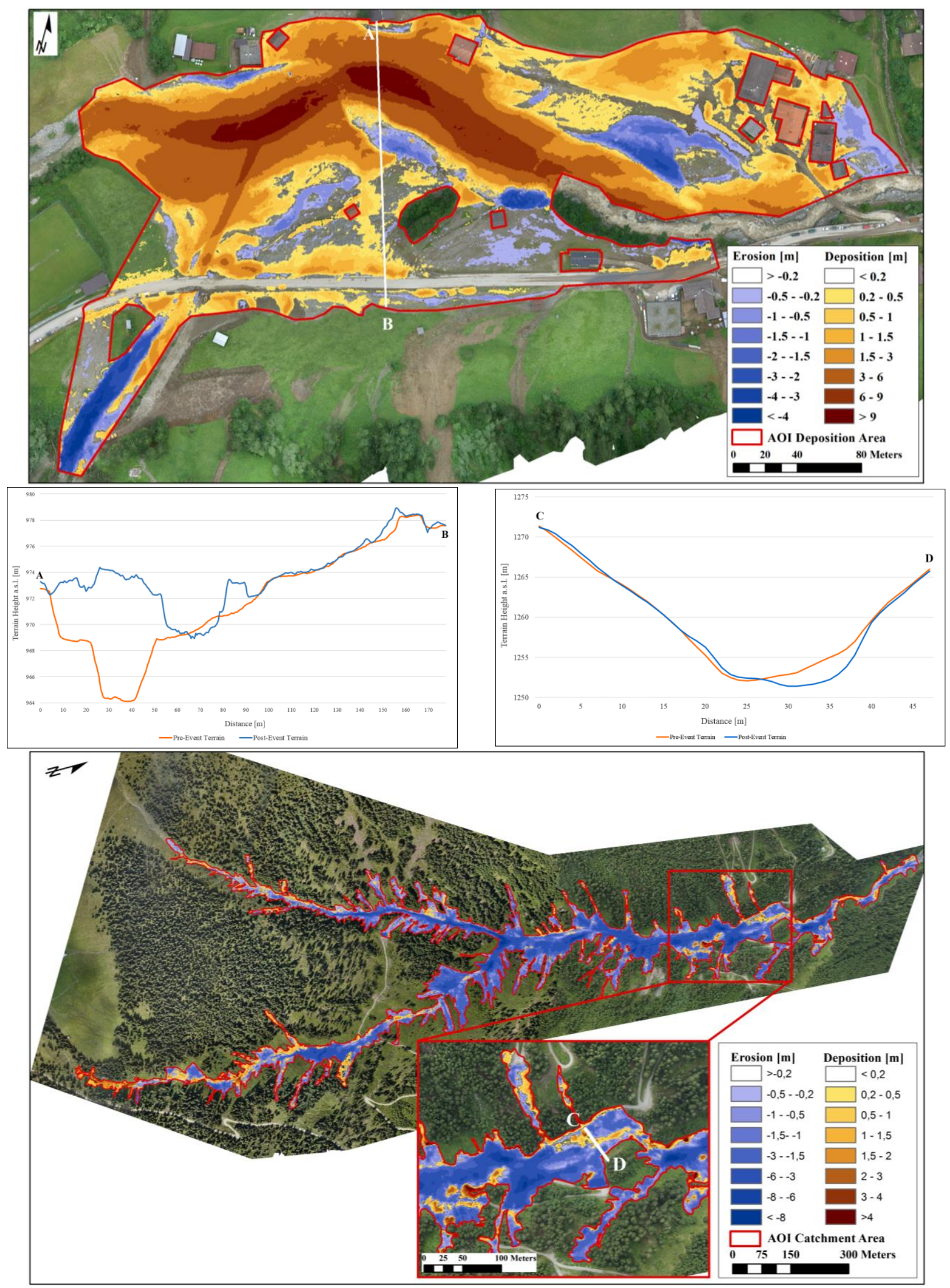

Figure 5. Results of the volumetric sediment budget calculation in the valley floor (top) and catchment (bottom); two cross-sections through the pre- (ALS) and post-event (UAS) DTM (centre left - deposition; centre right - catchment), the location of the crosssections are indicated by the white lines in both figures - A \& B / C \& D marking the starting and end points, respectively 


\section{CONCLUSIONS}

In this study, aerial imagery from a fixed-wing and a multicopter UAS were used to map an area of $2.8 \mathrm{~km}^{2}$ with the aim of determining the volumetric sediment budget of a debris flow event in the Austrian Alps in summer 2015. Using structure-from-motion photogrammetry and indirect georeferencing, high-resolution post-event orthophotos $(<0.05 \mathrm{~m} \mathrm{GSD})$ and DTMs $(<0.2 \mathrm{~m}$ GSD) of the valley floor and catchment were generated. A calculation of the sediment budget with pre-event ALS-data could be successfully performed at an accuracy of $0.05-0.5 \mathrm{~m}$ and precision of $0.05 \mathrm{~m}$ RMSE. The UAS-data can therefore reach an accuracy and precision comparable to manned aircraft data, but with the added benefits of higher flexibility, easier repeatability, less operational constraints and higher spatial resolution. However, the study also showed, that especially extensive $\left(>1 \mathrm{~km}^{2}\right)$, densely vegetated areas with large elevation differences, pose a challenge for UAS-based volume estimations, as indicated by the higher error margins in the catchment.

This study represents one of the very few published attempts to use UAS-based imagery and photogrammetric techniques to map the consequences of a debris flow event. The results from this UAS-campaign provided the authorities with a highresolution documentation of the debris flow's spatial extent and magnitude, as well as decision support for mitigation measure planning (e.g. planning mitigation measures).

\section{ACKNOWLEDGEMENTS}

The authors would like to express their sincere gratitude to: Austrian Service for Torrent and Avalanche Control - especially Manfred Pittracher \& Anne Jenner (funding, field work and event analysis); Martin and Lukas Buxbaum of Austro Drones (UAS flights); Patrick Fritzmann of Provincial Government of Tyrol (ALS DEMs); Armin Graf, Bernadette Sotier and Klaus Suntinger of BFW (field work and UAS flights).

\section{REFERENCES}

AgiSoft LLC, 2016. Agisoft PhotoScan, professional edition, version 1.1.6 64 bit, Petersburg, Russia.

Aronica, G.T., Biondi, G., Brigandì, G., Cascone, E., Lanza, S., Randazzo, G., 2012. Assessment and mapping of debris-flow risk in a small catchment in eastern Sicily through integrated numerical simulations and GIS. Phys. Chem. Earth, Parts $A / B / C, 49$, pp. 52-63.

Ballesteros Cánovas, J.A., Stoffel, M., Corona, C., Schraml, K., Gobiet, A., Tani, S., Sinabell, F., Fuchs, S., Kaitna R., 2016. Debris-flow risk analysis in a managed torrent based on a stochastic life-cycle performance. Sci. Total Environ., 557-558, pp. 142-153.

Bhardwaj, A., Sam, L., Bhardwaj, A., Martin-Torres, F.J., 2016. LiDAR remote sensing of the cryosphere: Present applications and future prospects. Remote Sens. Environ., 177, pp. 125-143.

Briese, C., Fortner, R., Sager, P, Pfeiffer, N., 2013. Vom Modellflughobby $\mathrm{zu}$ unbemannten Flugsystemen für die Geodatenerfassung. Österreichische Zeitschrift für Vermessung und Geoinformation (VGI), 101, pp. 64-74.
Bühler, Y., Adams, M.S., Bösch, R., Stoffel, A., 2016. Mapping snow depth in alpine terrain with unmanned aerial systems (UAS): potential and limitations. The Cryosphere Discuss., 9, pp. 1-36.

Bull, J.M., Miller, H., Gravley, D.M., Costello, D., Hikuroa, D.C.H., Dix, J.K., 2010. Assessing debris flows using LIDAR differencing: 18 May 2005 Matata event, New Zealand. Geomorphology, 124 (1-2), pp. 75-84.

Colomina, I. \& Molina, P., 2014. Unmanned aerial systems for photogrammetry and remote sensing: A review. ISPRS Journal of Photogrammetry and Remote Sensing, 92, pp. 79-97.

Dall'Asta, E., Delaloye, R., Diotri, F., Forlani, G., Fornari, M., Morra di Cella, U., Pogliotti, P., Roncella, R., Santise, M., 2015. Use of UAS in a high mountain landscape: The case of Gran Sommetta rock glacier (AO). ISPRS International Archives of the Photogrammetry, XL-3/W3, pp. 391-397.

Danzi, M., Di Crescenzo, G., Ramondini, M., Santo, A., 2013. Use of unmanned aerial vehicles (UAVs) for photogrammetric surveys in rockfall instability studies. Rend. Online Soc. Geol. It., 24, pp. 82-85.

Dietrich, A. \& Krautblatter, M., 2016. Evidence for enhanced debris-flow activity in the Northern Calcareous Alps since the 1980s (Plansee, Austria). Geomorphology, in press.

Drechsler, S., 2015. Meteorologisches Gutachten zum Starkniederschlagereignis am 6. und 7. Juni 2015 in Sellrain in Tirol. Gutachten Nummer 2015/IN/001646.

Elkadiri, R., Sultan, M., Youssef, A. M., Elbayoumi, T., Chase, R., Bulkhi, A. B., Al-Katheeri, M. M., 2014. A Remote sensing-based approach for debris-flow susceptibility assessment using artificial neural networks and logistic regression modeling. IEEE J. Sel. Top. Appl., 7(12), pp. 48184835 .

Fliri, F., 1998. Naturchronik von Tirol: Tirol- OberpinzgauVorarlberg- Trentino, Beiträge zur Klimatographie von Tirol. Universitätsverlag Wagner, Innsbruck, Austria, pp. 163.

Gregoretti, C., Degetto, M., Boreggio, M., 2016. GIS-based cell model for simulating debris flow runout on a fan. J. Hydrol., 534, pp. 326-340.

Han, Z., Chena, G., Lia, Y., Tangc, C., Xub, L., Hea, Y., Huangc, X., Wanga, W., 2015. Numerical simulation of debrisflow behavior incorporating a dynamic method for estimating the entrainment. Eng. Geol., 190, pp. 52-64.

Harwin, S., Lucieer, A., Osborn, J., 2015. The impact of the calibration method on the accuracy of point clouds derived using unmanned aerial vehicle multi-view stereopsis. Remote Sensing, 7 (9), pp. 11933-11953.

Hugenholz, C.H, Whitehead, K., Brown, O.W., Barchyn, T.E., Moorman, B.J., LeClair, A., Riddell, K., Hamilton, T., 2013. Geomorphological mapping with a small unmanned aircraft system (sUAS): Feature detection and accuracy assessment of a photogrammetrically-derived digital terrain model Geomorphology, 194, pp. 16-24. 
Jenner, A. 2015. Ereignisdokumentation Seigesbach nach dem Hochwasserereignis in Sellrain/Tirol am 7.6.2015. 17. Geoforum Umhausen 15.-16. Oktober 2015 Tagungsband, pp. 101-110.

Lindner, G., Schraml, K., Mansberger, R., Hübl, J., 2016. UAV monitoring and documentation of a large landslide. Applied Geomatics, (8), 1, pp. 1-11.

Lucieer, A., Turner, D., King, D.H., Robinson, S.A., 2013. Using an Unmanned Aerial Vehicle (UAV) to capture microtopography of Antarctic moss beds. Int. J. Appl. Earth Obs., 27, pp. 53-62.

Mancini, F., Dubbini, M., Gattelli, M., Stecchi, F. Fabbri, S. Gabbianelli, G., 2013. Unmanned Aerial Vehicles (UAV) for High-Resolution Reconstruction of Topography: The Structure from Motion Approach on Coastal Environments. Remote Sens., 5, pp. 6880-6898.

Nolan, M., Larsen, C., Sturm, M., 2015. Mapping snow depth from manned aircraft on landscape scales at centimeter resolution using structure-from-motion photogrammetry. The Cryosphere, 9, pp. 1445-1463.

Oberndorfer, S., Fuchs, S., Rickenmann, D., Andrecs, P., 2007. Vulnerabilitätsanalyse und monitäre Schadensbewertung von Wildbachereignissen in Österreich. BFW-Berichte, 139, Vienna.

ORF, 2015. News report from the Austrian Broadcasting Corporation (ORF) on 9 June 2015 (http://tirol.orf.at/news/ stories/2715184; accessed 28 March 2016).

Pellegrino, A.M., Scotto di Santolo, A., Schippa, L., 2015. An integrated procedure to evaluate rheological parameters to model debris flows. Eng. Geol., 196, pp. 88-98.

Rickenmann, D., Laigle, D., McArdell, B.W., Hübl, J., 2006. Comparison of 2D debris-flow simulation models with field events. Computat. Geosci., 10, pp. 241-264.

Rosnell, T. \& Honkavaara, E., 2012. Point cloud generation from aerial image data acquired by a quadrocopter type micro unmanned aerial vehicle and a digital still camera. Sensors, 12, pp. 453-480.

Ryan, J. C., Hubbard, A. L., Box, J. E., Todd, J., Christoffersen, P., Carr, J. R., Holt, T. O., Snooke, N., 2015. UAV photogrammetry and structure from motion to assess calving dynamics at Store Glacier, a large outlet draining the Greenland ice sheet. The Cryosphere, 9, pp. 1-11.

Scheidl, C., Rickenmann, D., Chiari, M., 2008. The use of airborne LiDAR data for the analysis of debris flow events in Switzerland. Nat. Hazards Earth Syst. Sci., 8, pp. 1113-1127.

Sotier, B., Graf, A., Kammerlander, J., 2013. Einsatz von UAV im alpinen Gelände: Erfahrungsbericht und Anwendungsbeispiel aus der Naturgefahrenpraxis. Österreichische Zeitschrift für Vermessung und Geoinformation (VGI), 101 (2+3), pp. 110-118.

Theule, J., Liébault, F., Laigle, D., Loye, A., Jaboyedoff, M., 2015. Channel scour and fill by debris flows and bedload transport. Geomorphology, 243, pp. 92-105.

Tonkin, T.N., Midgley, N.G., Graham, D.J., Labadz, J.C., 2014. The potential of small unmanned aircraft systems and structure- from-motion for topographic surveys: A test of emerging integrated approaches at Cwm Idwal, North Wales. Geomorphology, 226, pp. 35-43.

Trimble, 2015. GPS Pathfinder Office Software Help.

Turner, D., Lucieer, A., Watson, C., 2012. An automated technique for generating georectified mosaics from ultra-high resolution unmanned aerial vehicle (UAV) imagery, based on structure from motion (SfM) point clouds. Remote Sensing, 4, pp. 1392-1410.

Vander Jagt, B., Lucieer, A., Wallace, L., Turner, D., Durand, M., 2015. Snow Depth Retrieval with UAS Using Photogrammetric Techniques, Geosciences, 5, pp. 264-285.

Weibel, R. \& Heller, M., 1991. Digital terrain models. In: Maguire, D.J., Goodchild, M.F. Rhind, D.W.: Geographical Information Systems - Principles and Applications. Volume 1: Principles. Longman Scientific Technical, pp. 269-97, New York.

Wen, Q., He, H., Wang, X., Wu, W., Wang, L., Xu, F., Wang, P., Tang, T., Lei, Y., 2011. UAV remote sensing hazard assessment in Zhouqu debris flow disaster. Proc. SPIE, Remote Sensing of the Ocean, Sea Ice, Coastal Waters, and Large Water Regions, 8175.

Willi, C., Graf, C., Deubelbeiss, Y., Keiler, M., 2015. Methods for detecting channel bed surface changes in a mountain torrent - experiences from the Dorfbach torrent. Geogr. Helv. 70, pp. 265-279.

Youssef, A.M., Al-kathery, M., Pradhan, B., El-sahly, T., 2016. Debris flow impact assessment along the Al-Raith Road, Kingdom of Saudi Arabia, using remote sensing data and field investigations. Geomatics, Natural Hazards and Risk, (7), 2, pp. 620-638.

\section{APPENDIX}

\begin{tabular}{|l|c|c|}
\hline & $\begin{array}{c}\text { BFW Multiplex } \\
\text { Mentor }\end{array}$ & $\begin{array}{c}\text { Austro Drones } \\
\text { X18 }\end{array}$ \\
\hline UAV type & $\begin{array}{c}\text { Fixed-wing } \\
\text { (custom-built) } \\
1.63 \text { (wing span) }\end{array}$ & $\begin{array}{c}\text { Octocopter (X8 } \\
\text { configuration) } \\
0.96 \text { (diameter } \\
\text { excl. props) } \\
\text { Eimensions [m] }\end{array}$ \\
$\begin{array}{c}1.17 \text { (fuselage) } \\
1 \text { electrical, } \\
\text { brushless motor } \\
(680 \text { watts) }\end{array}$ & $\begin{array}{c}\text { brushless motors } \\
\text { (840 watts each) }\end{array}$ \\
Flight time [minutes] & $30-40$ & $15-25$ \\
Max. range [m] & $<1500$ & $<500$ \\
Max. take-off weight & 3 & 14 \\
[kg] & & \\
\hline
\end{tabular}

Table 3. Technical specifications of UAS

\begin{tabular}{|l|c|c|}
\hline & Sony NEX 5 & Sony Alpha 7R \\
\hline Sensor type & APS-C & Full frame \\
Sensor size [mm] & $23.5 \times 15.6$ & $35.8 \times 23.9$ \\
Sensor resolution [MP] & 14 & 36 \\
ISO range & $100-25,600$ & $100-25,600$ \\
Weight [g] & 380 & 594 \\
Lens [mm] & 16 (prime lens) & 35 (prime lens) \\
\hline
\end{tabular}

Table 4. Technical specifications of the UAS-sensors 